\title{
World, U.S. and Florida Avocado Situation and Outlook ${ }^{\mathbf{1}}$
}

\section{Edward Evans and Sikavas Nalampang ${ }^{2}$}

The purpose of this article is to highlight the major trends and developments in the world, U.S., and Florida avocado industries. The analysis covers the post-WTO (World Trade Organization) implementation period from 1996 to 2005.

\section{World Situation and Outlook}

Avocado is believed to be native to tropical America. There are three main races of avocado: Mexican, Guatemalan, and West Indian. The fruit is a large berry consisting of a single large seed surrounded by a buttery pulp. Fruit color varies among green, black, red, and purple. Typically, avocados do not ripen until they are picked or fall to the ground. Mature fruit size varies considerably depending upon cultivar and growing conditions. Fruit is popularly eaten fresh, in salads, or used to make guacamole and other dishes. Although it originated in the Americas, the tree is now widely dispersed and can be found in several tropical and subtropical areas.

World production of avocados in 2004 is estimated at 3.45 million tons, slightly less than the 3.49 million tons recorded in the previous year. Between 1996 and 2004, production grew at an average annual rate of $4.1 \%$, increasing from 2.5 million tons in 1996 to the current level. Table 1 shows the world's top ten avocado producing countries. Together they accounted for over $75 \%$ of the world's production of avocados in 2004.

Mexico is by far the largest producer, accounting for $33.2 \%$ of global production in 2004. The 2004 Mexican crop was estimated at 1.14 million tons, the same as in the previous year. Production in 2005 was expected to increase substantially due to more bearing acreages, favorable weather conditions, and phytosanitary programs. Indonesia is the second largest producer with 244,000 tons in 2004 (7.1\% of global production). Next is the United States with a 2004 crop of 203,000 tons (5.9\% of global production). Other countries in the top ten and their respective shares of world production of avocados in 2004 include Brazil (5.6\%), Colombia (5.5\%), Chile (5.1\%), Dominican Republic (4.5\%), Peru (3.4\%), China (2.7\%), and Ethiopia (2.6\%).

Global exports of avocados reached 541,000 tons in 2004 (up $18 \%$ over the previous year), and were valued at US $\$ 605.74$ million. Table 2 shows the top ten major avocado exporting countries. As can be seen in Table 2, Mexico and Chile dominate the

1. This is EDIS document FE639, a publication of the Food and Resource Economics Department, Florida Cooperative Extension Service, Institute of Food and Agricultural Sciences, University of Florida, Gainesville, FL. Published May 2006. Please visit the EDIS website at http://edis.ifas.ufl.edu.

2. Edward Evans, Assistant Professor, and Sikavas Nalampang, Research Assistant, Food and Resource Economics Department, Tropical Research and Education Center, Homestead, FL, Florida Cooperative Extension Service, Institute of Food and Agricultural Sciences, University of Florida, Gainesville, FL.

The Institute of Food and Agricultural Sciences (IFAS) is an Equal Opportunity Institution authorized to provide research, educational information and other services only to individuals and institutions that function with non-discrimination with respect to race, creed, color, religion, age, disability, sex, sexual orientation, marital status, national origin, political opinions or affiliations. U.S. Department of Agriculture, Cooperative Extension Service, University of Florida, IFAS, Florida A. \& M. University Cooperative Extension Program, and Boards of County Commissioners Cooperating. Larry Arrington, Dean 
export trade with shares of $27.6 \%$ and $23.1 \%$, respectively. Next are Israel (11.9\%) and Spain $(10.8 \%)$. Other major exporters include Netherlands, Peru, Dominican Republic, France, and the United States.

World imports of avocados increased from 284,000 tons in 1996 to 539,000 tons in 2004. The United States is the number one importer of avocados. In 2004, it imported 160,000 tons, or $29.7 \%$ of total avocado imports (Table 3). In second position is France with imports of 113,000 tons (21.1\%), followed by Netherlands (6.3\%), United Kingdom (6.1\%), and Japan (5.9\%). Other major importers in the top ten are Canada (3.9\%), Colombia (3.4\%), Germany (3.3\%), El Salvador (2.5\%), and Spain $(2.4 \%)$ [FAOSTAT].

The export market for avocados will likely increase (currently less than 16\% of the global market is traded). Factors influencing the avocado export market include all-around improvements and innovations in post-harvest and shipping technologies; continued reductions in horticultural commodity trade barriers; strong global demand for avocados amidst the promotion of health benefits; and increased acreages in some of the major producers, particularly Mexico and Chile.

\section{U.S. Production, Imports, and Exports of Avocados}

\section{Production}

The U.S. production of avocados occurs in three regions: California, Florida, and Hawaii. California is by far the largest producer, accounting for $90 \%$ of production, on average, followed by Florida with about $9 \%$ and Hawaii with less that $1 \%$. Avocados grown in California are mainly of the Hass variety, characterized by "purplish-black skin." Hass avocados are grown mainly in California's southern coastal region in San Diego, Riverside, Ventura, and Santa Barbara Counties. Most Florida avocados have green skins and are grown mainly in the Miami-Dade County area.

The United States is the third largest avocado producer behind Mexico and Indonesia (Table 1). As can be seen in Figure 1, U.S. production exhibits an erratic pattern (alternating high- and low-bearing years), which is characteristic of avocado production. In general, however, there has been an upward trend. Beginning with 190,000 tons produced in the $1996 / 97$ season, production grew to 233,000 tons in the 2003/04 season, and then fell to 179,000 tons in the 2004/05 season. The noticeable drop in production $(23.1 \%)$ was due mainly to adverse weather conditions in the main production areas in California. The decrease in production represented a significant loss to the industry (2004/05 U.S. avocado crop—estimated at \$292.75 million—was \$101.61 million less than the previous year).

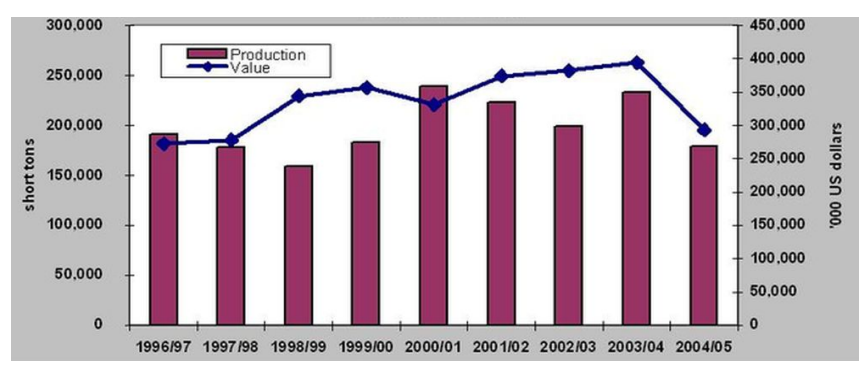

Figure 1. U.S. production of avocados (volume \& value), $1996 / 07$ to $2004 / 05$

Indications are that U.S. avocado production will recover in the upcoming season despite setbacks to the Florida avocado industry from hurricane damages in 2005. The United States Department of Agriculture (USDA), on the basis of information received from the California Avocado Commission, is projecting that the 2005/06 U.S. avocado crop will reach 272,000 tons. If this were to be realized, and even with a $60 \%$ reduction of the Florida crop as predicted by industry experts, total domestic production could reach about 282,000 tons in the 2005/06 season [USDA Fruit and Tree Nuts Outlook]. The increased domestic production, added to record imports (discussed below), could cause downward pressure on prices.

\section{Exports}

Table 2 shows that the United States is not a major exporter of avocados, accounting for a mere $1.5 \%$ of total exports in 2005. Only California avocados are exported, mainly to Canada, Japan, and Mexico. Except for a slight interruption of the trend in 2002 and 2004, the volume of U.S. avocado exports has trended downwards due to increased domestic demand for avocados. 


\section{Imports}

Since the late 1980s, the United States has shifted from being a net exporter of avocados to becoming a net importer, overtaking France in 2002 to become the world's number one importer of avocados. Figure 2 shows the trend in U.S. avocado imports over the period 1996 to 2005, with imports outnumbering domestic production for the first time in 2005. Between 1996 and 2005, imports increased from 28,000 tons to 291,000 tons, an average annual growth rate of approximately $30 \%$. The largest (by volume) single-year increase occurred in 2005, with imports increasing by 131,000 tons (from 160,000 to 291,000 tons). This was due to sizeable increases in the volume of avocados imported from Mexico and Chile (discussed below). The 2005 avocado imports were valued at about US \$337 million.

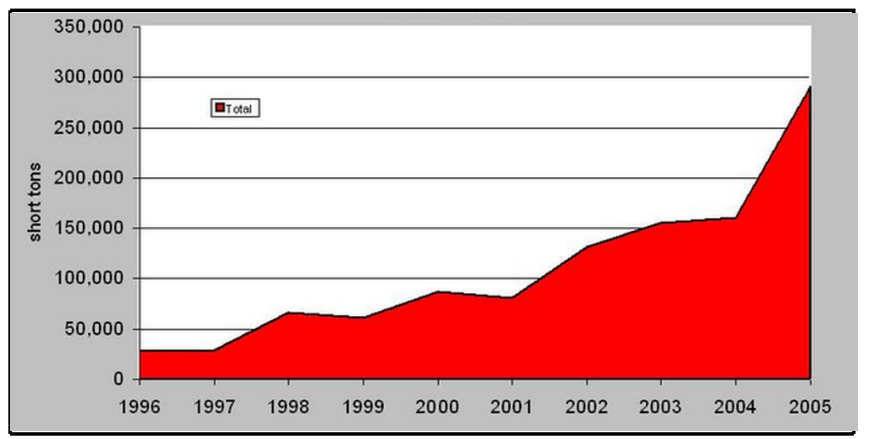

Figure 2. U.S. total imports of avocados (short tons), 1996-2005

The main sources of U.S. imports of avocados are Mexico, Chile, Dominican Republic, and New Zealand (Figure 3). Most of these imports are the Hass variety coming from Mexico, Chile, and New Zealand. Dominican Republic exports are mainly of the green-skin type similar to those produced in Florida. Mexico and Chile, with shares of $50.9 \%$ and $43.5 \%$ respectively, dominate the U.S. avocado import market, accounting for $94.4 \%$ of total imports in 2005. As illustrated in Figure 2, up until 2004, Chile was the main supplier of avocados to the United States, followed by Mexico. However, the situation now has been reversed. In 2005, Mexico more than tripled the amount of avocados it ships to the United States (from 42,000 tons in 2004 to 148,000 tons in 2005). This represents an increase of 106,000 tons $(247.4 \%)$ over the previous year. In comparison, imports from Chile increased by 23,000 tons $(22.7 \%)$ to reach 127,000 tons for the same period. Although imports of avocados from Dominican Republic are substantially less than those from Mexico and Chile the volume has been increasing over time. From 7,595 tons imported in 1996, imports have now more than doubled to 16,337 tons in 2005 (2,361 tons more than the quantity imported in the previous year).

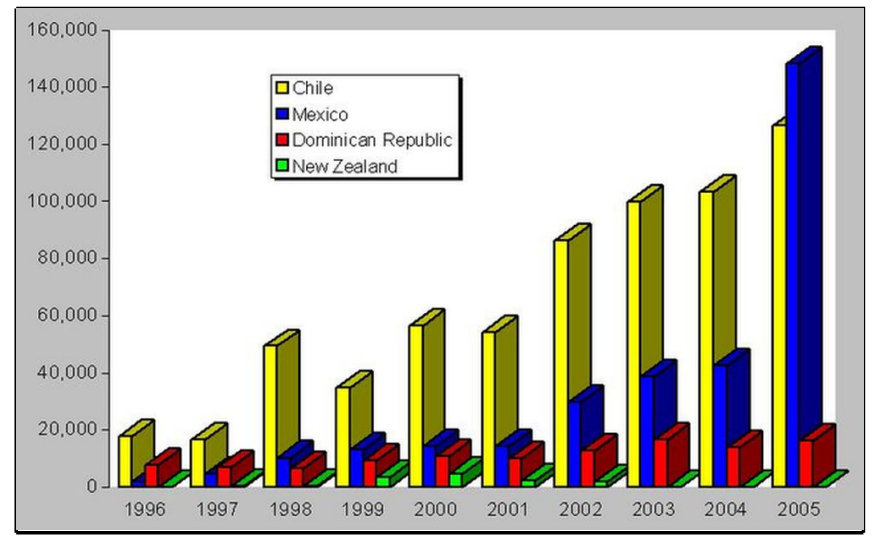

Figure 3. U.S. avocado imports by country (short ton), 1996-2005

The main driving force behind the sharp increase in imports of avocados entering the United States is the elimination of trade restrictions on avocado imports from Mexico. While Mexico is the world's largest producer of avocados, for a long time it was shut out of the U.S. market for phytosanitary reasons. In 1993, the importation ban was partially lifted, allowing entry of Mexican avocados into the state of Alaska. Then, in November 1997, more restrictions were lifted, allowing Mexico to ship fresh avocados to 19 northeastern states and the District of Columbia during a four-month period from November through February. In November 2001, the number of states allowed to import Mexican avocados was increased to 31 and the length of the shipping period was extended from October to April. Since January 2005, Mexico has been allowed to ship to 47 states (excluding California, Florida, and Hawaii) year-round. Full market access to all 50 states will be permitted beginning January 2007. Although there were no restrictions on avocados exported from Chile and Dominican Republic, the recent signing of bilateral trade agreements between these countries and the United States should make it easier for these countries to ship avocados to U.S. markets as efforts are made to further promote trade between the countries. The upward trend in avocado imports is 
expected to continue due to strong U.S. domestic demand and to increased production in the exporting countries (more acreage, phytosanitary programs, and trade agreements).

\section{U.S. Consumption of Avocados}

The U.S. consumption of avocados has increased considerably within recent times, more than doubling since 1996 (from 218,000 tons in 1996 to 516,100 tons in 2005). Per capital consumption increased from 1.53 pounds in 1996 to 3.00 pounds in 2005. Several factors are responsible for the increased consumption of avocados, including year-round availability of fresh avocados due to imports, lower avocado prices, a rapidly growing Hispanic population, the promotion of the health benefits of avocado, and increased disposable income.

A larger portion of the current domestic demand is being satisfied from imports. Figure 4 illustrates the changes in share of domestic consumption (production plus net imports) due to increased imports over the period 1996 to 2005. Share increased from less than $15 \%$ in 1996 to $30 \%$ in 1998 , $40 \%$ in 2002, and 55\% in 2005. Come 2007, when Mexico is allowed to ship to all 50 U.S. states, import share is expected to increase again.

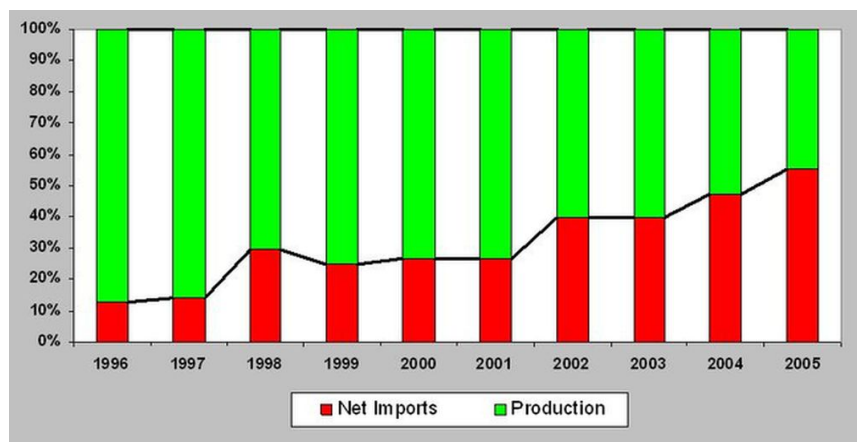

Figure 4. Net import share of consumption, 1996-2005

\section{The Florida Avocado Industry}

\section{Production}

The Florida avocado industry consists of about 6,600 bearing acres, 737 growers, and 35 registered avocado handlers and shippers (Census of Agriculture, 2002). Over $99 \%$ of the avocado acreage is located in southwest Miami-Dade County. As shown in Table 4, $87.7 \%$ of farms with farm sizes less than 15 acres account for $31.6 \%$ of total bearing acreage, while $7.3 \%$ of farms with 25 acres and more account for $60.0 \%$ of the total bearing acreage.

The green skin avocados produced in south Florida fall into two main categories: West Indian and Guatemalan. These two main categories comprise 60 avocado varieties that mature at different times during the season in various weights and sizes. As a consequence, yields per acre vary depending on production techniques and varieties grown. As in the case in California, there is a tendency of alternate-year bearing, implying high yields one year and lower yields the next.

Figure 5 highlights the trends in volume and value of production over the period 1996/97 to 2001/05. In general, production remained relatively flat from 1996/97 until 2002/03, when it increased by $34.8 \%$ over the previous season due to new bearings from groves replanted with higher-yielding varieties and increased planting density after Hurricane Andrew in 1992. However, there was a sharp decline in the 2003/04 crop due to extreme cold temperatures during the flowering season, which badly affected fruit settings. As can be seen from Figure 5, production resumed an upward trend in the following season. The 2004/05 Florida avocado crop (estimated at 28,000 tons) was valued at approximately $\$ 14.45$ million. This represents a $64.7 \%$ increase over the 2003/04 season, but less than the 31,000 tons recorded in the 2002/03 season. The industry again suffered a major setback from hurricane damages in 2005. Consequently, industry experts are projecting that the $2005 / 06$ crop will be about 11,000 tons, or about $60.0 \%$ below last year's production.

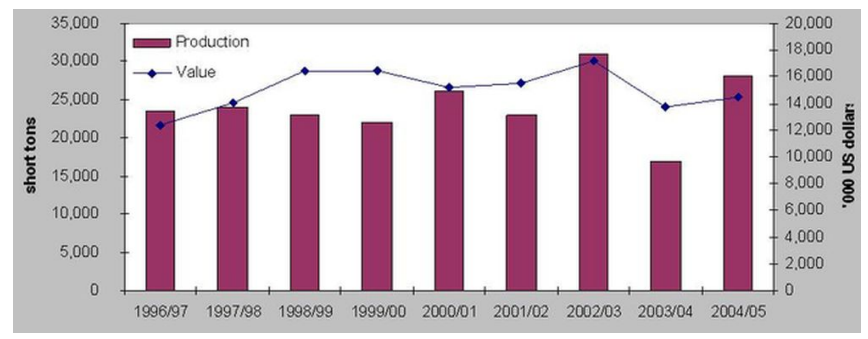

Figure 5. Florida avocado production (volume \& value), $1996 / 97$ to $2004 / 05$ 


\section{Farm Gate Price}

The bulk (80\%) of the avocados produced in Florida is sold outside the state; hence, the industry is an important revenue generator for Florida. Federal Marketing Order 915 (in existence since 1954) regulates production practices and harvesting procedures, such as the size and quality of the fruit, packing and shipping containers, and shipping dates. The Order is aimed at increasing grower returns by promoting orderly marketing conditions while ensuring consumer satisfaction. Permits must be obtained for anyone wishing to sell over 55 pounds of avocados per day. As a consequence, most of the avocados grown in Florida are sold to the packing houses.

The marketing season begins in May and ends in February or early March, with the bulk of shipments occurring from July through September. Figure 6 shows the shipping patterns for Florida, Mexico, Chile, Dominican Republic, and New Zealand. Prior to 2005, the bulk of Florida's avocados were marketed in a "window of opportunity," which enabled growers to obtain favorable prices because the bulk of the Florida commodity was sold after the peak shipping periods in California, before peak shipments from Chile, and at times when there were relatively few imports from Mexico and Dominican Republic. However, since 2005, this "window of opportunity" has eroded due to Mexico being allowed year-round avocado shipments to U.S. markets. As Figure 6 indicates, the quantity of avocados on the market has increased since Mexico began shipping during this period. This will no doubt add downward pressure to the prices that Florida growers receive.

Figure 7 shows the actual and inflation-adjusted trends of the prices the growers received over the period 1996/97 to 2004/05. For example, between 1996/97 and 1999/00, prices increased from US \$528 per ton ( $\$ 0.26$ per pound) to US $\$ 748$ per ton ( $\$ 0.37$ per pound), or by $41.7 \%$. However, with the exception of a slight recovery in 2001/02 and a spike in 2003/04 caused by a sharp drop in production, prices have been decreasing. In the 2004/05 season, growers received a price of US $\$ 516$ per ton $(\$ 0.26$ per pound), which represents only $76.6 \%$ of the

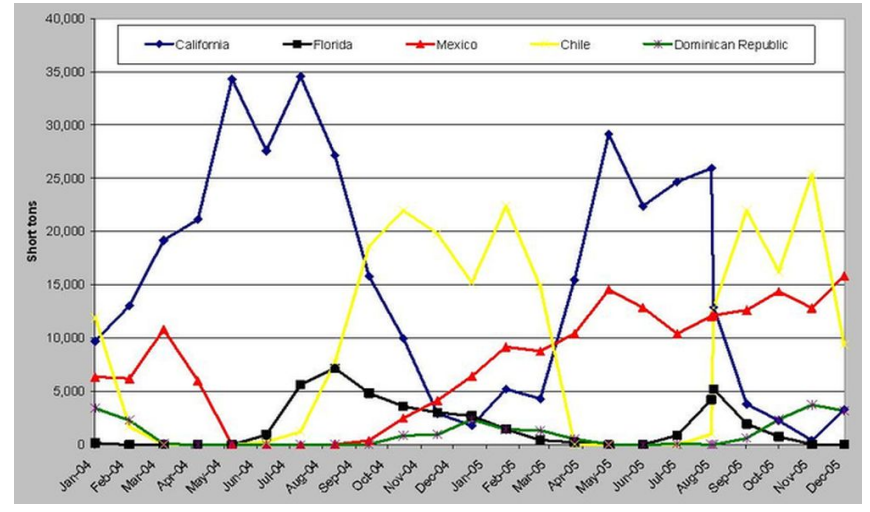

Figure 6. Avocado monthly shipments, January 2004 to December 2005

$1999 / 00$ to $2002 / 03$ five-year average ( $\$ 674$ per ton or $\$ 0.34$ per pound). As shown in Figure 7, the downward trend in prices becomes more obvious when prices are adjusted for inflation.

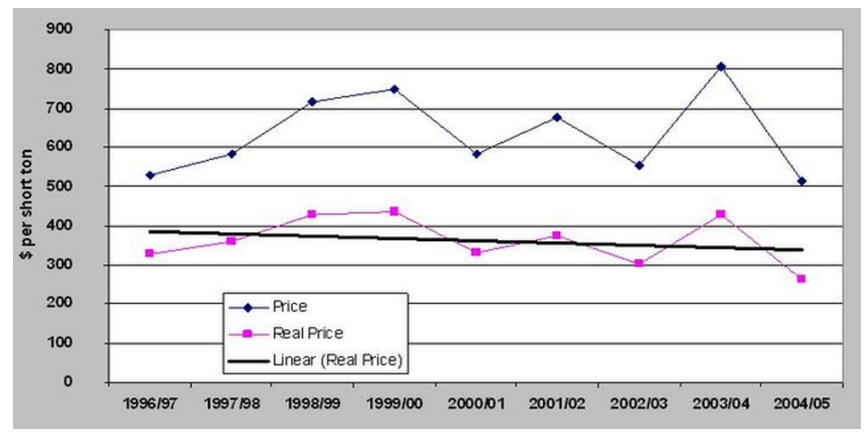

Figure 7. Florida grower prices (nominal \& inflation adjusted $1982-84=100$ )

Changes in price seem increasingly less responsive to changes in production levels. For example, in the 1999/00 season, production decreased by $4.2 \%$ and prices increased by $22.6 \%$ (implying that a $1 \%$ reduction in quantity resulted in almost a $6 \%$ increase in the prices). In contrast, in the 2003/04 season, production decreased by $45 \%$ and prices increased by $45 \%$ (i.e., a $1 \%$ decrease in quantity resulted in only a $1 \%$ percent increase in prices). The implication is that consumers are no longer willing to pay higher prices for Florida avocados when cheaper priced imports are available. This is borne out by the fact that avocado imports totaled only 28,000 tons in the $1999 / 00$ season and 155,000 tons in the 2003/04 season. Domestic producers can no longer expect to make up revenues from higher prices in years where there are significant shortfalls in domestic production. 


\section{Summary}

World production of avocados is expected to rise in the 2005/07 period due to increased production in the major avocado exporting countries, improvement in phytosanitary conditions, reductions in trade barriers, and advances in transportation and post-harvest technologies. As a consequence, Mexico and Chile will dominate the export trade while the United States will remain the number one importer of avocados.

Domestically, U.S. avocado consumption will continue to increase because of lower prices, increased availability, and a growing Hispanic population. Over the coming seasons, U.S. avocado production is likely to resume its upward trend, despite setbacks to the Florida avocado industry. The upward trend in avocado imports is expected to continue due to strong U.S. domestic demand, increased production in Mexico and Chile; and trade agreements allowing year-round imports of Mexican avocados to all 50 U.S. states beginning 2007. Despite the expected increase of U.S. per capita consumption of avocados, domestic prices may decrease or remain the same due to the combination of increased domestic production and increased imports.

\section{References}

FAOSTAT Online. http://faostat.fao.org/.

NASS-USDA. 2002. Census of Agriculture Online. Washington, D.C.: National Agricultural Statistics Service, United States Department of Agriculture, Washington, D.C. http://www.nass.usda.gov/Census_of_Agriculture/ index.asp.

USDA Foreign Agricultural ServiceOnline. Washington, D.C. http://www.fas.usda.gov/ustrade.

USDA Fruit and Tree Nuts Outlook. 2006. FTS-320, Washington, D.C. (January 26). http://usda.mannlib.cornell.edu/reports/erssor/ specialty/fts-bb/2006/fts320.pdf. 
World, U.S. and Florida Avocado Situation and Outlook

Table 1. World's top ten major avocado producers, 1996-2005 ('000 tons).

\begin{tabular}{|c|c|c|c|c|c|c|c|c|c|c|}
\hline Countries & 1996 & 1997 & 1998 & 1999 & 2000 & 2001 & 2002 & 2003 & 2004 & Share \\
\hline & & \multicolumn{8}{|c|}{ - } & $(\%)$ \\
\hline Indonesia & 157 & 143 & 144 & 139 & 160 & 156 & 262 & 282 & 244 & 7.07 \\
\hline United States & 190 & 177 & 159 & 183 & 239 & 223 & 199 & 233 & 203 & 5.88 \\
\hline Brazil & 125 & 139 & 81 & 174 & 145 & 151 & 159 & 179 & 191 & 5.54 \\
\hline Chile & 66 & 61 & 109 & 90 & 108 & 121 & 154 & 154 & 176 & 5.10 \\
\hline $\begin{array}{l}\text { Dominican } \\
\text { Republic }\end{array}$ & 110 & 99 & 94 & 78 & 90 & 122 & 162 & 165 & 154 & 4.46 \\
\hline Ethiopia & 0 & 0 & 0 & 0 & 86 & 87 & 88 & 89 & 90 & 2.60 \\
\hline World Total & 2,512 & 2,446 & 2,552 & 2,701 & 2,938 & 3,103 & 3,297 & 3,486 & 3,452 & \\
\hline
\end{tabular}

Table 2. World's top ten major avocado exporting countries, 1996-2005 ('000 tons).

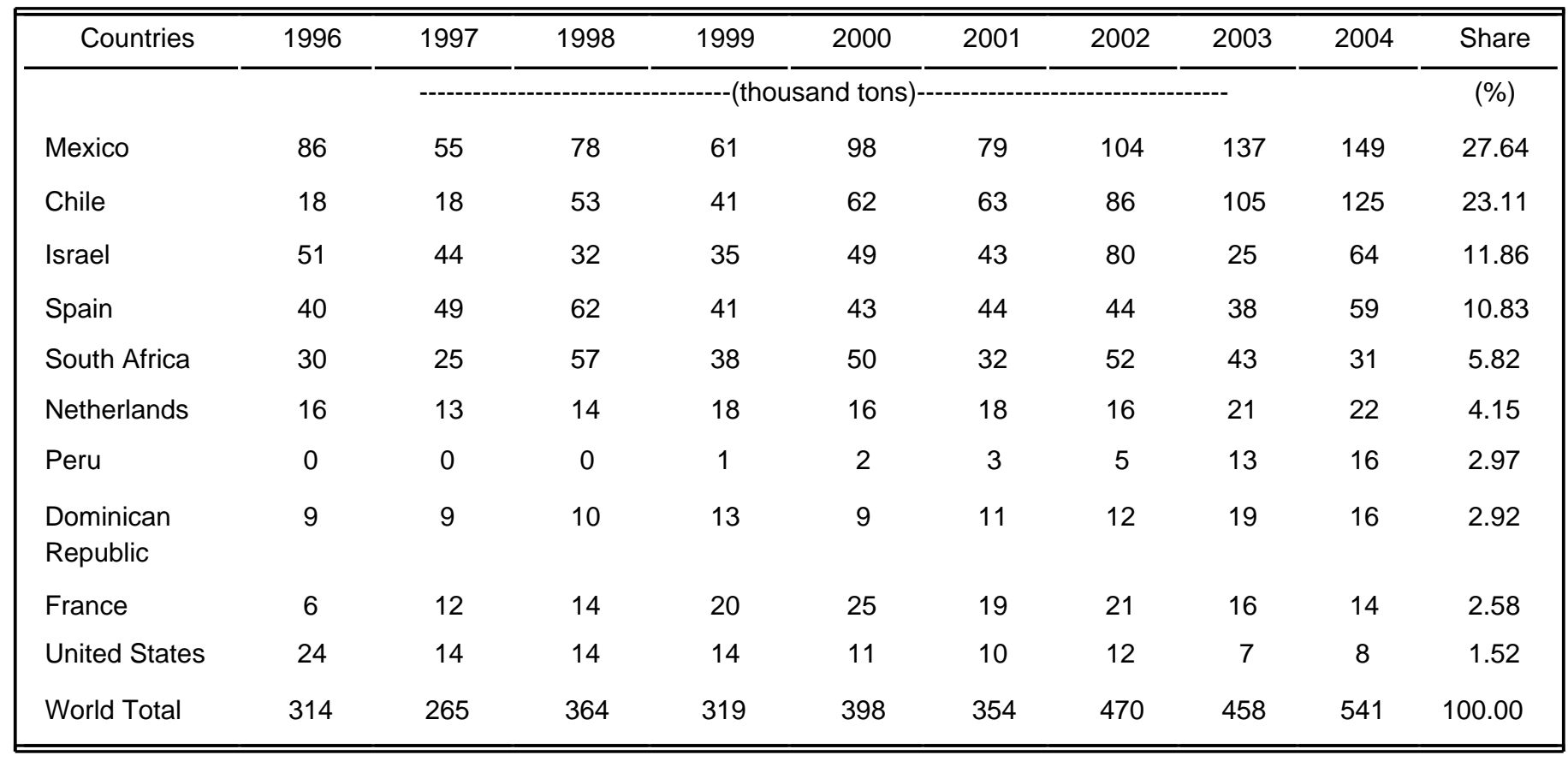


World, U.S. and Florida Avocado Situation and Outlook

Table 3. World's top ten major avocado importing countries, 1996-2005 ('000 tons).

\begin{tabular}{|c|c|c|c|c|c|c|c|c|c|c|}
\hline Countries & 1996 & 1997 & 1998 & 1999 & 2000 & 2001 & 2002 & 2003 & 2004 & Share \\
\hline & & \multicolumn{8}{|c|}{ - } & $(\%)$ \\
\hline United States & 28 & 29 & 67 & 61 & 86 & 81 & 131 & 155 & 160 & 29.66 \\
\hline France & 111 & 110 & 112 & 91 & 116 & 109 & 109 & 99 & 113 & 21.04 \\
\hline Netherlands & 13 & 15 & 23 & 19 & 21 & 23 & 29 & 30 & 34 & 6.25 \\
\hline $\begin{array}{l}\text { United } \\
\text { Kingdom }\end{array}$ & 18 & 22 & 26 & 20 & 25 & 26 & 32 & 29 & 33 & 6.06 \\
\hline Japan & 7 & 7 & 9 & 8 & 15 & 12 & 15 & 26 & 32 & 5.92 \\
\hline Canada & 12 & 10 & 12 & 11 & 14 & 14 & 16 & 17 & 21 & 3.91 \\
\hline Colombia & 9 & 10 & 1 & 9 & 11 & 8 & 11 & 12 & 18 & 3.40 \\
\hline Germany & 17 & 14 & 17 & 14 & 12 & 15 & 17 & 17 & 21 & 3.29 \\
\hline El Salvador & 6 & 3 & 5 & 9 & 13 & 10 & 12 & 13 & 14 & 2.52 \\
\hline Spain & 3 & 4 & 4 & 3 & 4 & 6 & 6 & 12 & 13 & 2.42 \\
\hline World Total & 284 & 276 & 338 & 297 & 378 & 358 & 447 & 474 & 539 & 100.00 \\
\hline
\end{tabular}

Table 4. Structure of the Florida avocado industry.

\begin{tabular}{|lccccc|}
\hline \hline $\begin{array}{c}\text { Avocado Acres } \\
\text { Harvested }\end{array}$ & $\begin{array}{c}\text { Number of } \\
\text { Farms }\end{array}$ & $\begin{array}{c}\text { Total Acres } \\
\text { Harvested }\end{array}$ & $\begin{array}{c}\text { Average Acres } \\
\text { per Farm }\end{array}$ & $\begin{array}{c}\text { Cumulative \% } \\
\text { of Farms }\end{array}$ & $\begin{array}{c}\text { Cumulative } \\
\text { \% of Acres }\end{array}$ \\
\hline 0.1 to 0.9 & 112 & 41 & 0.37 & 15.20 & 0.62 \\
1.0 to 4.9 & 338 & 665 & 1.97 & 61.06 & 10.68 \\
5.0 to 14.9 & 196 & 1,384 & 7.06 & 87.65 & 31.62 \\
15.0 to 24.9 & 34 & 556 & 16.35 & 92.27 & 40.04 \\
25.0 to 49.9 & 25 & 762 & 30.48 & 95.66 & 51.57 \\
50.0 to 99.9 & 19 & 1,143 & 60.16 & 98.24 & 68.86 \\
100.0 acres or more & 13 & 2,058 & 158.31 & 100.00 & 100.00 \\
Total & 737 & 6,609 & 8.97 & & \\
\hline \hline
\end{tabular}

